Article

\title{
Supply Chain Management and Business Sustainability Synergy: A Theoretical and Integrated Perspective
}

\section{Zabihollah Rezaee}

300 Fogelman College Administration Building, Fogelman College of Business and Economics, The University of Memphis, Memphis, TN 38152-3120, USA; zrezaee@memphis.edu; Tel.: +1-(901)-678-4652; Fax: +1-(901)-678-0717

Received: 20 November 2017; Accepted: 15 January 2018; Published: 22 January 2018

\begin{abstract}
Global business organizations face the challenges of adapting proper sustainability strategies and practices to effectively respond to social, ethical, environmental, and governance issues while improving financial performance in creating value for their shareholders. Business sustainability enables the integration of financial economic sustainability performance and non-financial environmental, social, ethical, and governance sustainability performance dimensions into the corporate culture, supply chain management and business models in creating shared value for all stakeholders. Business literature has provided mixed evidence of the tension, and possible link, between financial and non-financial sustainability performance dimensions and sustainability theories have yet to sufficiently address this tension. This paper attempts to fill this void by shedding light on the link between various dimensions of sustainability performance, their integrated effect on creating shared value for all stakeholders and their implications for supply chain sustainability. This paper examines the synergy between business sustainability and supply chain management by presenting a framework consisting of sustainability theories, sustainability performance dimensions, sustainability shared value concept, and sustainability best practices. Companies can use the suggested framework in integrating both financial and non-financial sustainability initiatives into their supply chain sustainability from production design, purchasing and inbound logistics, and manufacturing process to distribution and outbound logistics.
\end{abstract}

Keywords: sustainability; performance; managerial decision-making; business activities; supply chain sustainability

\section{Introduction}

Business sustainability has advanced in the past decade from branding and greenwashing to strategic imperative while global business organizations continue to focus on the achievement of sustainability performance as investors demand and regulators require the disclosure of sustainability performance information. Recently more than 14,000 global public companies (compared to less than 100 companies a decade ago) disclose their financial economic sustainability performance (ESP) and non-financial environmental, social, ethical, and governance (ESEG) sustainability performance information [1,2]. Sustainability guidelines for the most part are still voluntary [2,3], and there are a number of divergent sustainability theories [1,4,5]. In this evolving and highly opaque field of business sustainability [6], where the relation between ESP and ESEG may be viewed as complementing/completing or conflicting/competing [1], there is a need for a strategic imperative and pragmatic approach to business sustainability. In recent years, business organizations are facing the challenges of adapting proper sustainable supply chain strategies and practices to effectively respond to ESEG issues while creating sustainable financial performance and value for their shareholders. 
There is a growing demand for integrating both financial ESP and non-financial ESEG dimensions of sustainability into supply chain management. Supply chain sustainability (SCS) is advancing in delivering long-term sustainable profitability while focusing on process innovations. This paper presents a framework consisting of theory and standard implications, sustainability performance dimensions, and sustainability reporting and assurance and their integration into SCS in creating shared value for all stakeholders.

The United Nations Global Compact's 2013 Global Business Sustainability Report, while underscoring the importance of SCS, states that it could be a roadblock to improved sustainability performance and encourages companies to engage their suppliers in the establishment of more sustainable practices by creating synergy between business sustainability and SCS [7]. Given the ever-growing attention to business sustainability and mixed empirical results of the possible link between financial ESP and non-financial ESEG dimensions of sustainability performance, this paper synthesizes the academic research on business sustainability in order to develop a framework that presents an integrated and holistic approach to business sustainability performance and reporting as well as its implications for SCS.

The establishment of a conceptual framework for SCS is challenging, as it requires identification of all constituencies and stakeholders who affect and are affected by sustainability, integration of all dimensions of sustainability performance to the supply chain, and application of relevant theories to supply chain management. Figure 1 presents a conceptual framework for SCS for both financial ESP and non-financial ESEG sustainability performance dimensions and related theories, key performance indicators, the shared value concept and proper disclosure. Following the literature review, Sections 3-6 of this paper further describe SCS components of the suggested framework.

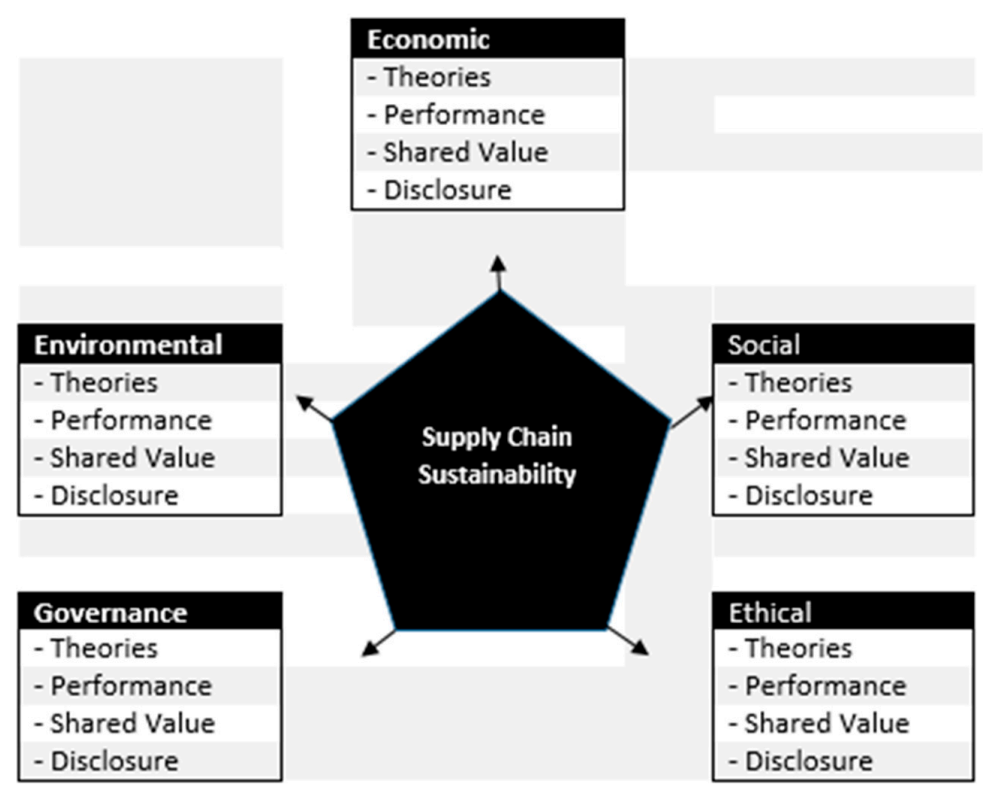

Figure 1. Supply Chain Sustainability Framework.

This study provides policy, practical, as well as educational implications and contributes to the extant sustainability literature in several ways. First, this paper is an attempt to reconcile the perceived conflict between obtaining sustainable financial performance by creating shareholder value and achieving non-financial ESEG sustainability by protecting the interests of other stakeholders. Second, the suggested sustainability framework enables business organizations to take their sustainability initiatives from the current branding, greenwashing, and publicity stage to the top of the agenda for their directors and executives to integrate into their corporate culture, infrastructure, supply chain management, and business models. Third, management can use the framework to integrate both 
financial ESP and non-financial ESEG sustainability performance dimensions into all facets of supply chain management from purchasing and inbound logistics, production design, and manufacturing processes to distribution, outbound logistics, customer services, social programs, and environmental initiatives. The proper establishment of SCS requires identification of all stakeholders and supply chain partners that affect, and are affected by, sustainability initiatives. Moreover, business organizations can explicitly recognize the benefits and downsides of a particular sustainability initiative (just as they do with shareholder value) and make the appropriate decisions for their particular sustainability activities. Finally, future research can use the framework to study the joint and integrated effects of financial ESP and non-financial ESEG sustainability performance on management decisions including strategic, operational, financing, and investment activities as well as risk assessment, supply chain management, and the possible impacts of sustainability performance disclosures on financial markets, society, and the environment.

The remainder of this paper is organized as follows: Section 2 provides the literature review. Sustainability theories are presented in Section 3. Section 4 describes sustainability performance. Sustainability shared value creation is presented in Section 5. Section 6 presents sustainability performance reporting and assurance. Relevance of business sustainability to supply chain sustainability is provided in Section 7. Discussion and conclusion are presented in Section 8.

\section{Sustainability Literature Review}

Business sustainability performance and reporting has been a topic of great interest in supply chain management literature. Cruz and Marques [8] define sustainability as a social objective with a keen focus on achieving the triple bottom line performance of profit, planet, and people. Rezaee [1] defines business sustainability as the process of achieving financial ESP in creating shareholder value while protecting the interests of all other stakeholders by focusing on non-financial ESEG sustainability performance. Several streams of research address sustainability performance and reporting and various aspects of sustainable supply chain management. The first stream of research consists of several studies $[9,10]$ investigate the relevance of environmental (green) and social initiatives to SCS by examining whether it pays to be green and socially responsible and how business organizations should deal with environmental and social issues. This stream of research focuses on the importance of social and environmental programs to companies' entire value chains from inbound and outbound logistics to processes, operations, finished products, customer interfaces, distribution channels, and customer services and find that SCS are gaining momentum. Simoes and Marques [11] argue that performance analysis is a relevant matter and thus there are various approaches (parametric and non-parametric) in evaluating economic performance of the waste services.

The second stream of research debates the potential benefits and costs of sustainability and whether sustainability investments in environmental and social initiatives pay off in terms of customers' satisfaction and perception toward products and services [12-15]. Tate et al. [16] postulate that firms are increasingly under pressure from their stakeholders to integrate both financial ESP and non-financial ESEG sustainability performance into their SCS strategies and the institutional pressure is the main driver of the move toward such integration. Foerstl et al. [17] identify five interdependent contextual drivers of SCS, which are grouped into stakeholder-related drivers, process-related drivers and product-related drivers. This stream of research also uses the term SCS to highlight managerial decisions and actions in achieving financial ESP (management of materials, capital flows, production process, and information) and non-financial ESEG sustainability performance activities in dealing with environmental and social issues and their comparison with supply chain management best practices [18-20].

The third stream of research $[13,21,22]$ examines multiple theories of sustainability performance. Several theories, including agency theory [23-25], institutional/legitimacy theory [26,27], signaling/disclosure theory [28,29], stakeholder theory [30-33], and stewardship theory [34,35] are relevant to business sustainability. The next section presents these theories and their implications 
for SCS. According to stakeholder theory, sustainability performance dimensions (ESP and ESEG) are viewed by stakeholders as value-added activities that create stakeholder value. In compliance with the signaling/disclosure and legitimacy/institutional theories, good firms (high sustainability performance) differentiate themselves from bad firms (low sustainability performance) by signaling their legitimacy as good corporate citizens through corporate transparency and a corporate culture that is linked to reputation management. Stewardship theory suggests that management is steward of all capitals and resources including financial, human, manufacturing, SCS, environmental and social.

Another stream of research deals with the use of standards, particularly the International Organization for Standardization (ISO) standards to promote compliance with ISO 9000 on improving product quality, ISO 14,000 in advancing environmental management, reporting, and auditing, and ISO 26,000 in focusing on the triple bottom line of profit, people, and planet. Prior research on sustainability standard adoption has shed light on the issues of symbolic adoption [36,37], standard enforcement [38,39], and sustainability ratings and certifications [40,41]. Sustainability standards are currently voluntary, predefined procedures, and best practices that systematically assess and communicate the firm's ESG sustainability performance.

The final stream of related research, while underscoring the importance both financial ESP and non-financial ESEG sustainability performance, provides contradictory evidence of business ESEG sustainability programs and their impacts on earnings and firm value. Several studies [42-45] address the emergence of sustainability development pertaining to social and environmental issues, their relevance to accounting and finance, their impacts on sustainability, accounting, reporting, and auditing, and the need for academic research in sustainability. Specifically, Unerman and Chapman [46] state that Accounting for sustainability development represents a complex and pressingly important area of research. However, there is a need for greater theoretical development and diversity in business sustainability in general and SCS in particular. Golicic and Smith [47] report that SCS results in improved firm's financial ESP by finding an association between environmental supply chain practices and both accounting and market-based financial and operational performance. The 2013 Global Corporate Sustainability Report released by the United Nations Global Compact addresses the state of corporate sustainability today and presents the actions taken by companies worldwide in integrating sustainability to their strategies, operations, and SCS [7]. The report finds that companies are increasingly focusing on SCS and making progress on setting expectations for their suppliers to integrate sustainability into their strategies and practices.

Friedman [48] argues that the responsibility of a corporation is to earn profits and thus, ESEG programs are distributions of shareholder wealth in the pursuit of managers' own interests. Others $[49,50]$ provide empirical evidence that suggests that ESEG sustainability initiatives improve the firm's future financial performance. Anecdotal evidence suggests that ESEG sustainability performance affects financial performance (ESP) and thus stock prices and firm value [50,51]. The KPMG report suggests that firms use financial and non-financial KPIs and drivers of sustainable performance through operational efficiency, customer satisfaction, talent management, and innovation [52]. Ng and Rezaee [53] find that financial ESP sustainability performance is associated with cost of equity capital and that non-financial ESEG sustainability performance moderates such association. Jain, et al. [54] report that ESP and ESEG sustainability performance dimensions are linked and that short sellers avoid firms with high ESEG scores and tend to target firms with low ESEG scores. Huang and Watson [55] review research on corporate social responsibility (CSR) published in the last decade in 13 of the top accounting journals and conclude it is difficult to measure financial impacts of CSR initiatives in terms of their associated costs and potential benefits. Lys et al. [56] report that CSR expenditures are neither charity nor do they improve financial performance. Taken together, prior research provides mixed evidence of the link between financial ESP and non-financial ESEG sustainability performance dimensions.

Prior research, while examining several aspects of SCS, has not sufficiently addressed a holistic approach of integrating both financial ESP and nonfinancial ESEG dimensions of sustainability 
performance into firms' entire value chains from strategic planning by top level management to production design, purchasing, inbound logistics, manufacturing process, distribution, outbound logistics, marketing, and customer services. This paper is an attempt to integrate all dimensions of sustainability performance into SCS using a relevant theoretical framework and best practices as presented in the following sections. Thus, it contributes to the literature by presenting sustainability theories, performance, and their integrated effects on creating shared value for stakeholders as well as their implications for supply chain sustainability as depicted in Figure 1.

\section{Sustainability Theory Implications for Supply Chain Sustainability}

The concept of sustainability performance suggests that a firm must extend its focus beyond maximizing short-term shareholder profit by considering the impact of its operations and SCS on all stakeholders including the community, society, and the environment [1,2]. Several theories including agency/shareholder, stakeholder, signaling, legitimacy, institutional, and stewardship can provide an explanation of the interrelated ESG and ESEG dimensions of sustainability performance and their integrated link to SCS, as discussed in this section. Agency/shareholder theory defines the relationship between shareholders (principals) and management (agent) and identifies the potential conflicts of interest between management and shareholders. Shareholder theory views management as only accountable to shareholders for creating shareholder value and whose interests may diverge from those of their shareholders [25]. Agency theory explains the principle-agent relationships and the objective of supply chain management in improving ESP performance in creating shareholder value with little, if any focus on other non-financial ESEG dimensions of sustainability performance.

Freeman's [30] stakeholder theory and Jensen's [32] "enlightened value maximization" recognize the maximization of sustainable performance and the long-term value of the firm as the criterion for balancing the interests of all stakeholders. Jensen [32] states "A firm cannot maximize value if it ignores the interest of its stakeholders." In this regard, stakeholders are classified as internal stakeholders such as shareholders, management and employees and external stakeholders including creditors, customers, suppliers, government, society and the environment. Stakeholder theory [30] and enlightened value maximization theory [32] promote creation of value for all stakeholders through both financial ESP and non-financial ESEG sustainability performance. While stakeholder theory recognizes the importance of protecting the interests of all stakeholders including shareholders, customers, suppliers, creditors, employees, society, and the environment, has failed to address any possible tensions among stakeholders.

Legitimacy theory posits that business organizations face social and political pressure to preserve their legitimacy by fulfilling their social contract. Business organizations, by focusing on the achievement of both financial ESP and non-financial ESEG sustainability performance and proper disclosure of sustainability performance, fulfill the 'social contract' and gain the support of society to obtain legitimacy $[57,58]$. Nonetheless, legitimacy theory indicates that non-financial ESEG dimensions of sustainability performance can be achieved for all stakeholders without providing any solutions for shared value creation among diverge stakeholders [1,59].

Signaling theory recognizes that there are two aspects of business sustainability-namely sustainability performance and sustainability disclosure. Signaling theory suggests that companies signal financial ESP sustainability performance information as reflected in financial reports and voluntary disclose their non-financial ESEG sustainability performance to differentiate their good and superior sustainability performance from other companies with less favorable sustainability performance [29]. Signaling theory is important in disclosing both financial ESP and non-financial ESEG dimensions of sustainability performance information and thus is most relevant to sustainability disclosure rather than sustainability performance.

Institutional theory suggests that business organizations are a platform for individuals who share common goals and advocates the role of normative influences in business decisions that are relevant to a group of individuals in addressing many conditions, challenges, opportunities, and issues 
that lead the structure to institutionalization [60-62]. Institutional theory posits that the institutional environment and social matters, as well as corporate culture and governance can be more effective than external measures (laws, regulations) in creating sustainable performance. This theory focuses on business sustainability by considering a firm as an institution to serve all stakeholders including human and social needs [63] and thus the goal of SCS should be to achieve common purposes.

Finally, stewardship theory in recognizing the role of internal and external stakeholders in a business organization, should be responsible stewards in creating shared value by contributing to wealth creation for shareholders as well as contributing to the wellbeing of customers, employees, society, and the environment. Stewardship theory $[34,35]$ helps to explain potential tensions among various dimensions of sustainability performance in creating shared value. Business sustainability provides a framework to better understand the implications of stewardship theory in the management-stakeholder relationship with multidimensional performance incentives. In their role as stewards of companies' assets and resources, management's primary role is to improve sustainable performance in order to create shared value. Management, as the steward of business resources, has the primary role for improving both financial ESP and non-financial ESEG sustainability performance and managing related risks, maximizing utilization of all capitals from strategic to financial, reputational, manufactured, human, social, and environmental in order to create shared value for all stakeholders.

Sarkis, Zhu and Lai [64] discuss nine theories relevant to the green supply chain management including complexity, ecological modernization, information, institutional, resource based-review, resource dependence, social network, stakeholder and transaction cos economics theories. Touboulic and Walker [65] argue that existing sustainability theories in supply chain management are not adequate and all-inclusive and more theories need to be developed to conceptualize sustainability supply chain management. These aforementioned theories except for stewardship theory (e.g., shareholder, stakeholder, signaling, legitimacy, and institutional), have systematically ignored the integration among various dimensions of sustainability performance, their interactions and implications for SCS, and their possible tensions and constraints imposed on the main business objective of creating shareholder value. These theories have used a narrow and parochial aspect of sustainability performance that emphasizes either ESP under the shareholder theory or ESEG sustainability performance under stakeholder, signaling, legitimacy, and institutional theories. However, under stewardship theory, management acts as the steward of strategic capital, financial capital, human capital, social capital, and environmental capital and acts as the active and long-term oriented steward of all stakeholders including shareholders and individuals involved with SCS. Stewardship theory can provide a means by which supply chain management can engage with all stakeholders, and focusing on the achievement of long-term improvements for financial ESP and non-financial ESEG sustainability, as further elaborated in the next section.

\section{Sustainability Performance}

Sustainability has the potential to assist management as it faces greater pressure to reduce costs in the short-term while building the business foundation for sustainable performance, sustainable supply chain management, and long-term growth. The link between business, society, and the environment is complex and often tense, and management must find ways to address the potential tension and maximize both ESP and ESEG sustainability performance. Yet, a cohesive business sustainability concept is lacking in explaining the multidimensional and apparently conflicting aspects of sustainability performance. Significant debate has taken place about whether ESEG initiatives and programs, where the cost is immediate and tangible and the related benefits may not materialize in the short-term and are often non-measurable (e.g., CSR), constitute a legitimate activity for a corporation [1,2]. Sustainability performance on ESEG is typically considered an externality beyond the disclosure of ESP, which can be viewed positively or negatively by investors and other market participants. 
Examples of positive externalities are initiatives to establish effective corporate governance measures, mitigate non-compliance costs with applicable laws, rules and regulations, create diversified and independence board of directors, promote majority voting by shareholders, link executive compensation to performance, promote good brand and reputation, take on environmental initiatives regarding climate change and greenhouse gas emissions, ensure high-quality and safe products and customer satisfaction, establish ethical workplaces, create job and promote fair employment $[1,66]$. Examples of negative externalities are bad branding and reputation, ineffective corporate governance measures, inappropriate tone at the top by the board of directors, aggressive management, noncompliance with regulations, ineffective systems of checks and balances, excessive risk-taking by executives, irresponsible corporate social activities, natural resource depletion, pollution, and human rights abuses $[2,53,54]$.

Business sustainability is about creating a proper balance of short- and long-term continuous improvement of both financial ESP and non-financial EESG sustainability performance. Management may take diametrically opposing approaches to business sustainability. One approach is that sustainability is a matter of compliance with some voluntary initiatives and philanthropy unrelated to the core business and goal of creating shareholder value. The other emerging approach considers sustainability in enabling opportunities to create shared value by focusing on the continuous improvements of short-term performance and long-term growth. This section reviews the increasing specificity of sustainability performance in the global economic arena, and lays out a typology of financial ESP and non-financial ESEG dimensions of sustainability performance and the aspects of continuous improvements toward addressing the overriding objective of sustainability in creating shared value. These orientations reflect a wide variance in the understanding of how organizational activities should be linked into sustainability performance and map well onto SCS.

Sustainability is often viewed as a continuum of binary decisions representing increasing obligations, rather than encompassing critical trade-offs [67] and ambiguity [6]. Consequently, disagreement on approaches has not been easily brooked, given a tendency toward a "more is better" assumption; in turn, researchers, executives, businesses, and professional organizations reside in different camps, or (most lamentably) self-identify as "interested in sustainability" —or not. In fact, recent global initiatives have significantly systematized the parameters of sustainability under an ESEG rubric that includes "economic imperatives" as a key priority, and highlights the role of ethics throughout [68].Therefore, not being interested in sustainability performance will increasingly resemble the absurdity of not being interested in financial performance in the study of organizations. Pagell and Shevchenko [22] suggest that future supply chain management research and treat environmental and social performance dimensions of SCS as important as economic performance. There are many legitimate reasons and rationales for focusing on the continuous improvement of financial ESP and non-financial ESEG sustainability performance including the maximum utilization of scarce resources, cost-efficiency and effectiveness, customer satisfaction, rewarding relationships with suppliers, attracting and maintaining talented employees, enhancing business reputation, and creating stakeholder value. By focusing on different SCS activities and their integrated links to the ESP and ESEG dimensions of sustainability performance, the relationship and tensions between different components of sustainability performance can be evaluated.

Tensions among the various dimensions of sustainability performance can occur in several ways, including tensions between financial ESP and non-financial ESEG sustainability performance and tensions within the ESEG components themselves. The most severe tension (and thus potential conflict of interest) is between the financial and non-financial dimensions of sustainability performance, as management is unwilling to actively engage and invest in ESEG sustainability because of the possibility of taking away funds available to shareholders. The second level of tension and potential conflict of interest is among the components of ESEG, as management is constrained by scarce resources, and has to be selective when deciding on the scope, extent, and type of ESEG initiatives. 
Management compliance with ISO 26,000 standards is expected to lead not only to a more sustainable financial ESP return, but also to a close alignment of the interests of businesses and investors with the interests of the global environment and society and a positive impacts on SCS. Supply chain management should analyze the potential tensions between various ESP and ESEG dimensions of sustainability performance (and thus possible conflicts of interests between stakeholders) by realizing that the true measure of success for corporations should be determined not only by their reported earnings, but also by their governance, social responsibility, ethical behavior, and environmental initiatives. Management should manage both the financial ESP and non-financial ESEG dimensions of sustainability performance by integrating ESEG into SCS, particularly when there is a conflict between the corporate goals of maximizing profits and the social and environmental goals of CSR. For example, tobacco companies may increase their shareholder wealth by selling their products, but at the risk of being detrimental to the health of customers. Supply chain management implements strategies and programs to align corporate goals with those of society and the environment, and to minimize conflicts between the ESP and ESEG dimensions of sustainability performance caused by differences between private and social costs and benefits.

True measurement of performance including financial, human, social and environmental is both vital and challenging. Focus on all activities makes measurement crucial and the lack of standard performance indicators makes it difficult. Measurement of inputs and both ESP and ESEG activities such as earnings growth, the number of employee volunteer hours, initiatives to reduce greenhouse gas emission, the amount spent on community endeavors, the total number of people trained or involved in a particular initiative or activity need to be reported to stakeholders. Table 1 presents all five dimensions of sustainability performance and their related key performance indicators (KPIs) including the sourcing of raw materials and inputs for production; product innovations that lead to positive environmental, health, or society impacts; employee safety, training and diversity; compliance with ethical principles and human rights standards; and community initiatives in the areas of health and well-being, education, employment, and economic empowerment. 
Table 1. A Condensed List of Financial ESP and Non-Financial Sustainability ESEG Key Performance Indicators.

\begin{tabular}{|c|c|c|c|c|}
\hline Economic & Governance & Social & Ethical & Environmental \\
\hline $\begin{array}{l}\text { Economic } \\
\text { value generated } \\
\text { Revenues earned } \\
\text { Resources consumed } \\
\text { Costs recognized } \\
\text { Resources } \\
\text { obtained (assets) } \\
\text { Capital raised } \\
\text { Liabilities assumed } \\
\text { Expenses incurred } \\
\text { Earnings retained } \\
\text { Earnings distributed } \\
\text { Compensations paid } \\
\text { Financial risk assessed } \\
\text { Taxes paid } \\
\text { Research and } \\
\text { development invested } \\
\text { New products } \\
\text { discovered } \\
\text { Forecast, projections, } \\
\text { and other technical and } \\
\text { quantitative } \\
\text { market information } \\
\text { Financial Statements } \\
\text { (Balance sheet, Income } \\
\text { statement, Statement of } \\
\text { cash flow, } \\
\text { Owners' equity) } \\
\text { Note Disclosures } \\
\text { Accounting Policies } \\
\text { Segment Information } \\
\text { Business combination, } \\
\text { discontinued operation } \\
\text { Earnings Releases } \\
\text { Non-GAAP Financial } \\
\text { Measures } \\
\text { Accounting Policies } \\
\text { and practices } \\
\text { Stock prices }\end{array}$ & $\begin{array}{l}\text { Number of } \\
\text { board committees } \\
\text { Percentage of board } \\
\text { independence } \\
\text { Full independence of } \\
\text { board committees } \\
\text { Board diversity in terms } \\
\text { of ethnic, sex, } \\
\text { expertise, minority } \\
\text { Staggered board } \\
\text { Separation of the } \\
\text { position of the chair of } \\
\text { the board and chief } \\
\text { executive officer (CEO) } \\
\text { Board accountability } \\
\text { and liability } \\
\text { Number of } \\
\text { board meetings } \\
\text { Number of members in } \\
\text { the board } \\
\text { Percentage of insider } \\
\text { directors on the board } \\
\text { Number of members in } \\
\text { the audit committee and } \\
\text { their financial experts }\end{array}$ & $\begin{array}{l}\text { Percent of employees } \\
\text { who consider that their } \\
\text { business acts responsibly } \\
\text { Number of full-time } \\
\text { employees (FTE) } \\
\text { dedicated to social } \\
\text { investment projects } \\
\text { Funds raised per FTE for } \\
\text { non-profit and } \\
\text { humanitarian } \\
\text { organizations } \\
\text { Philanthropy as a } \\
\text { percent of (pretax) profit } \\
\text { Percentage of operating } \\
\text { income dedicated to } \\
\text { social contribution } \\
\text { Percent of suppliers that } \\
\text { affirmed business code } \\
\text { of conduct } \\
\text { Social contributions } \\
\text { spent per employee } \\
\text { policy } \\
\text { Number of initiatives to } \\
\text { promote greater } \\
\text { environmental } \\
\text { responsibility } \\
\text { Total investment in the } \\
\text { community } \\
\text { Donations and other } \\
\text { social expenses } \\
\text { Fair competition } \\
\text { Truthful advertising } \\
\text { Community } \\
\text { engagements }\end{array}$ & $\begin{array}{l}\text { Existence of business } \\
\text { codes of conduct } \\
\text { Description of social } \\
\text { and ethical activities } \\
\text { and projects } \\
\text { Diversity and equal } \\
\text { opportunities } \\
\text { Fair wages, contracts, } \\
\text { and benefits } \\
\text { Employee diversity } \\
\text { based on age, } \\
\text { specialization, gender, } \\
\text { and ethnicity } \\
\text { Number of employees, } \\
\text { turnover, and } \\
\text { hiring/firing } \\
\text { procedures } \\
\text { Whistleblowing } \\
\text { policies, programs, and } \\
\text { procedures } \\
\text { Employee productivity } \\
\text { Employee satisfaction, } \\
\text { competence, and } \\
\text { commitment } \\
\text { Customer satisfaction, } \\
\text { retention, and loyalty } \\
\text { Fair competition } \\
\text { Percent of eligible } \\
\text { employees who signed } \\
\text { the Code of Conduct } \\
\text { and Ethics } \\
\text { Resolution of conflicts } \\
\text { of interest }\end{array}$ & $\begin{array}{l}\text { Continuous } \\
\text { replacement of } \\
\text { nonrenewable of scarce } \\
\text { resources } \\
\text { Disclosure of } \\
\text { ecosystem changes } \\
\text { Disclosure of } \\
\text { gigajoules of total } \\
\text { energy consumed } \\
\text { Disclosure of metric } \\
\text { tons of total CO } 2 \\
\text { emitted } \\
\text { Disclosure of risk } \\
\text { exposure and } \\
\text { opportunities of } \\
\text { climate changes } \\
\text { Disclosure of toxic } \\
\text { chemical use and } \\
\text { disposal } \\
\text { Efficiency utilization of } \\
\text { unconventional } \\
\text { renewable and } \\
\text { nonrenewable natural } \\
\text { resources } \\
\text { Efficient use of } \\
\text { recycled materials } \\
\text { Environmental } \\
\text { profitability analysis } \\
\text { and assessment } \\
\text { Measurement of } \\
\text { resource depletion } \\
\text { Greenhouse gas } \\
\text { emissions in total and } \\
\text { intensity } \\
\text { Total waste } \\
\text { emission data } \\
\text { and }\end{array}$ \\
\hline
\end{tabular}

Source: [1].

\section{Sustainable Shared Value Creation}

Business organizations are criticized for primarily focusing on profit maximization and as a result, short-term shareholder value creation with minimal attention to the impacts of their operations on society and the environment. This short-termism behavior contrasts with the long-term view of business sustainability. As business sustainability gains more attention and is being integrated into the business culture and model, there has been a shift from the creation of shareholder value, to the development of "sustainable shared value creation" to protect the interests of all stakeholders. The concept of shared value is defined as "policies and practices that enhance the competitiveness of a company while simultaneously advancing the economic and social conditions in the communities in which it operates" [69]. Under the shared value creation concept, management focuses on financial ESP performance improvement of business operations in generating long-term shareholder value while maximizing the positive impacts of operations on society and the environment by creating shared value for all stakeholders. Business sustainability requires business organizations to refocus their business purpose to create shared value for all stakeholders. Business organizations should expand their mission to not only generate profit and create shareholder value, but also to ensure shared value for all stakeholders. The concept of shared value challenges the way management think about profits, philanthropy, sustainability, and development. Sustainable-shared value creation enable 
business organizations to integrate financial ESP with non- financial ESEG into business culture, SCS and corporate environments.

The emergence of business sustainability creates both opportunities for business involvement in value creation beyond economic imperatives to improve the ESEG profile of companies $[4,70]$ and challenges in allocating scarce resources subject to a variety of strategic, operational, financial, compliance, and reputational risks. Management may attempt to achieve short-term targets to create shareholder value [71] whereas business sustainability encourages management to focus on achieving long-term financial and non-financial ESEG performance sustainability $[1,2,53]$. The keen focus on optimizing short-term financial performance can cause management to overlook the importance of long-term and enduring ESP and ESEG sustainability performance in creating shared value.

Managers differ widely in their views and understanding of how to address apparently conflicting multidimensional aspects of sustainability, and often the amorphous nature of the sustainability concept has made it difficult to understand legitimate differences across corporations in their approaches to sustainability. Investors and public companies now focus on both financial and market long-term ESP performance indicators such as long-term stock prices, return on investment, return on assets, earnings growth, and research and development in measuring ESP. A survey of 1400 directors and executives reveals that boards and executives are "spending more time talking about leading indicators that reflect the long-term health of the company ... and sharpening their focus on the company's drivers of long-term value creation.". This survey addresses the key drivers of long-term value creation, metrics to measure performance, lagging key performance indicators (KPIs), leading KPIs, the right balance between leading and lagging KPIs and ways to communicate these KPIs to all stakeholders [72]. Academic research suggests that ESP is essential in creating shareholder value by examining the value-relevance of financial information and its link to stock prices and cost of capital. For example, Jain et al. and $\mathrm{Ng}$ and Rezaee $[53,54]$ find that firms with better ESP exhibit better financial and market performance and lower cost of equity and such a link between ESP and cost of equity is more pronounced in the presence of ESEG.

\section{Sustainability Performance Reporting and Assurance}

There are two aspects of business sustainability, namely sustainability performance (outside-in direction) and sustainability reporting (inside-out direction)) [53,59] and these two aspects are interrelated and integrated in discharging management responsibility and accountability to all stakeholders. Schaltegger and Wagner [73] and Burritt and Shaltegger [74] argue that the inside-out approach demonstrates management stewardship through the implementation of strategic plans and actions to achieve sustainability performance, whereas the outside-in approach reveals means by which management communicates its sustainability performance achievements to all stakeholders through either the financial reporting and / or voluntary disclosures to signal its superior sustainability performance. Prior research $[53,54,74]$ provides evidence that suggests sustainability performance and sustainability reporting are interrelated, and their integrated effects (impacts on accounting and market performance and cost of capital and firm value) demonstrate management responsibility and accountability to all stakeholders.

The format and content of integrated sustainability performance reporting is evolving rapidly. Sustainability reporting and assurance as of now is disclosed on a voluntary basis for the most part in compliance with guidelines of the Global Reporting Initiative [68], the International Integrated Reporting Council [75], and the Sustainability Accounting Standards Board [76]. However, there is more pressure and demand on management to disclose sustainability performance information and provide assurance on sustainability information [77]. Many public companies worldwide have responded to such reporting demands through integrated reporting in communicating financial ESP and non-financial ESEG to all stakeholders. Recently, several countries including Australia, Austria, Canada, China, Denmark, France, Germany, Malaysia, Netherlands, Sweden, Hong Kong, and the United Kingdom have adopted disclosure guidelines in reporting the various dimensions 
of sustainability reporting and it is expected that other countries to follow suit toward mandatory reporting of sustainability information [59]. A recent survey shows that 61 percent of respondents believe that public companies should be required to report on their ESEG sustainability indicators at least annually [78]. More than 14,000 global public companies issued stand-alone sustainability reports in 2015, compared with less than 500 companies in 2005 [1,59]. As investors and regulators continue to demand sustainability information and sustainability reporting becomes more standardized management should recognize a continuous interest in demand for sustainability information, and integrate it into corporate reporting and assurance.

\section{Relevance of Business Sustainability to Supply Chain Sustainability}

Business organizations worldwide are now recognizing the importance of sustainability performance and the link between financial ESP and non-financial ESEG sustainability performance. Justifications for business sustainability are moral obligation, social responsibility, maintaining a good reputation, ensuring sustainability, environmental consciousness, engaging in SCS, licensing to operate, and creating stakeholder value. In creating shared value for all stakeholders, corporations identify potential social, environmental, governance and ethical issues, then integrate them into their strategic planning and supply chain management. There are many factors of why a company should integrate sustainability performance to its supply chain management, including the pressure of the labor movement, development of moral values and social standards, the development of business education, and the change in public opinion about the role of business, environmental matters, governance, and ethical scandals. Companies which are, or aspire to be, leaders in sustainability are challenged by raising public expectations, increasing innovation, continuous quality improvement, effective governance measures, high standards of ethics and integrity, and heightened social and environmental problems.

Globalization has provided incentives and opportunities for business organizations, their stakeholders, and executives to influence their business sustainability initiatives and strategies and integrate them to their supply chain management. Corporations can choose from a variety of sustainability initiatives and performances with regard to the scope, extent and type of sustainability strategies that focus on different issues, functions, areas, and supply chain management. Although integrating the proposed framework of sustainability theories, ESP and ESEG sustainability performance, sustainable shared value creation and sustainability performance reporting and assurance, to SCS may be a challenging task, the failure to act can be detrimental to the company's success. Figure 1 and Sections 3-6 of this paper present a conceptual framework for SCS for both financial ESP and non-financial ESEG sustainability performance dimensions and their related theories, key performance indicators, the shared value concept and sustainability reporting and assurance. These attributes of business sustainability are relevant and important in achieving SCS and integrating sustainability into supply chain management in promoting best practices of SCS.

The best practices of supply chain sustainability are evolving as more business organizations continue to focus on and maximize various financial ESP and non-financial ESEG dimensions of their sustainability performance and other attributes as depicted in Figure 1 of sustainability framework. Table 2 presents the best practices of supply chain sustainability performance by a sample of high-profile companies across several industries in several countries. These best practices suggest integration of sustainability theories and the continuous performance improvement concept with a focus on both financial ESP and non-financial ESEG sustainability performance into SCS strategies, policies, and procedures. Management should develop and maintain proper sustainability programs and SCS strategies that provide a common ground for the integration of the suggested sustainability framework to their supply chain management that consist of: 
Table 2. Best practices of supply chain sustainability performance.

\begin{tabular}{|c|c|c|c|c|}
\hline Company & Country & Industry & $\begin{array}{l}\text { Sustainability } \\
\text { Performance }\end{array}$ & Best Practices of Supply Chain Sustainability \\
\hline $\begin{array}{l}\text { Airport } \\
\text { Authority }\end{array}$ & Hong Kong & Management & ESP and ESEG & $\begin{array}{c}\text { Effectively communicating ESP and ESEG sustainability } \\
\text { performance to stakeholders and properly disclosing } \\
\text { sustainability performance information. }\end{array}$ \\
\hline Bank Asia & Bangladesh & $\begin{array}{l}\text { Financial } \\
\text { Services }\end{array}$ & ESP,ESEG & $\begin{array}{l}\text { Uses the triple-bottom-line (TBL) of profit, people and } \\
\text { planet as its main guideline for action and integration } \\
\text { into supply chain management. }\end{array}$ \\
\hline $\begin{array}{l}\text { NORMA } \\
\text { Group }\end{array}$ & Germany & $\begin{array}{l}\text { Engineering/ } \\
\text { Supply Chain }\end{array}$ & ESP,ESEG & $\begin{array}{c}\text { Designs lightweight components to make products more } \\
\text { environmentally friendly. }\end{array}$ \\
\hline Novartis & Switzerland & Pharmaceuticals & ESEG & $\begin{array}{l}\text { Uses its worldwide logistics connections to ascertain } \\
\text { sustainability issues in all of its locations. }\end{array}$ \\
\hline
\end{tabular}

$\mathrm{Ng}$ and Rezaee [53] define ESP as long-term sustainable financial performance measured in terms of accountingbased measures (return on equity, sales), market-based measures (stock returns, market-book value) and long-term investments (R\&D and advertising). The terms corporate social responsibility (CSR) and ESEG sustainability have been interchangeably used in the literature. Consistent with Jain, Jain and Rezaee [54], Ng and Rezaee [53] CSR can be considered as part of ESEG sustainability. Prior research Ng and Rezaee [53]; Jain et al. [1,54]; and professional organizations Global Reporting Initiative [68] classify these five dimensions into financial economic performance (ESP) and non-financial environmental, social and governance (ESG) with ethics is integrated into other four dimensions.

- Employ the stewardship theory with a keen focus on all capitals from strategic to financial, reputational, manufactured, social, environmental, and human in creating accountability and stewardship for all capitals and stakeholders.

- Integration of continuous improvement for both financial ESP and non-financial ESEG sustainability performance into the business and investment analysis, supply chain management, and decision-making process.

- Development of SCS strategies for identification and selection of suppliers that focus on the achievement of their sustainability performance.

- Communication of the company's SCS strategies, practices, and expectations to major suppliers and customers to mitigate risks and foster corporate values and culture.

- Continuous assessment of the company's SCS to monitor and improve supply chain management, and identify challenging areas that need further improvements.

- Promotion of appropriate sustainability performance reporting and assurance in disclosing sustainability performance information to all stakeholders.

- Collaboration among all stakeholders to enhance the effectiveness of implementing sustainability programs and development including SCS strategies in creating shared value for all stakeholders.

- Promotion of product innovation and quality, customer retention and attraction, employee satisfaction and productivity through supply chain management.

- Link business sustainable performance to the company's strategy, business model, and SCS.

- Periodic disclosures of both financial and nonfinancial key performance indicators (KPIs) relevant to both financial ESP and non-financial ESEG sustainability performance to all stakeholders.

In summary, there are four implications of the suggested sustainability framework in this paper for businesses that try to integrate it to their supply chain management. First, the business sustainability framework for SCS is driven by and built on the stewardship theory, which requires management to be the steward of the company's resources and aim its SCS strategic decisions through the effective utilization of resources. Management, as the steward of business resources, has the primary role for improving sustainability performance and managing related risks, maximizing utilization of all capitals from strategic to financial, reputational, manufactured, human, social, and environmental 
in order to create shared value for all stakeholders. Second, the main goal and objective function for business organizations is to maximize firm value through SCS. The goal of firm value maximization can be achieved through continuous improvements of both financial ESP and non-financial ESEG sustainability performance. The ESP and ESEG sustainability performance dimensions are interrelated and complement/complete each other and thus they should be integrated to supply chain management. Third, the focus of business sustainability and SCS should be on creating long-term and sustainable shared value for all stakeholders including investors, creditors, suppliers, customers, employees, the environment, and society. Finally, companies should effectively and transparently communicate their financial ESP and non-financial ESEG sustainability performance and SCS to all stakeholders by periodically releasing their sustainability reports.

\section{Discussion and Conclusions}

This paper examines the integration of business sustainability into supply chain management through continuously improving both the financial ESP and non-financial ESEG dimensions of sustainability performance in generating shared value creation for all stakeholders. This paper suggests several ways that management can focus on sustainable and long-term performance including providing both financial/quantitative and non-financial/qualitative sustainability information to investors, focusing on long-term performance and its continuous improvements, and communicating sustainability performance and SCS information to all stakeholders. In this context, sustainability focuses on business activities that generate long-term ESP and thus ensure firm value maximization as well as voluntary activities that result in the achievement of ESEG sustainability performance that concerns all stakeholders.

This business sustainability and SCS framework presented in this paper, while maximizing profitability in creating shareholder value, optimizes business, environmental, and social activities to create shared value in protecting the interests of all stakeholders. This framework acknowledges that sustainability decision-making is also complex and fraught with uncertainty, as is decision-making for shareholder value, because sustainability is also about making investments in light of an uncertain future. It is challenging to develop a conceptual sustainability paper in the highly opaque field of corporate sustainability where tensions exist between financial ESP and non-social ESEG, where sustainability guidelines for the most part are still voluntary, and where there are a number of divergent sustainability theories. However, the theoretical framework developed in this paper and presented in Figure 1 integrates ESP and ESEG sustainability performance dimensions into managerial decision-making under uncertainty related to the potential complementary/completing and or competing/conflicting tensions among sustainability performance dimensions. It discusses sustainability performance dimensions in terms of their contributions to shared value creation in the context of stewardship theory. Integration of both ESP and ESEG dimensions of sustainability performance to supply chain management enables companies to conserve scare resources, optimize production processes, identify product innovations, achieve cost efficiency and effectiveness, increase productivity and promote corporate reputation.

Organizations of all types and sizes can integrate the suggested sustainability framework, depicted in Figure 1, consisting of sustainability theories, continuous improvements of both ESP and ESEG sustainability performance, shared value creation, and sustainability disclosures into their corporate culture, business model, and SCS in effectively achieving their missions and goals. This study focuses the development of KPIs for both financial ESP and non-financial ESG dimensions of sustainability performance to improve the quality, reliability, and transparency of corporate sustainability disclosures. This paper provides policy, practical and research implications for legislators, regulators, and standard-setting bodies and businesses in developing guidelines for integrated sustainability reporting in disclosing ESP and ESEG sustainability performance and their integration into corporate culture, business environment, and SCS strategies. 
Acknowledgments: The funding grants from the Thompson-Hill Chair of Excellence at the University of Memphis in support of this research paper is greatly appreciated.

Conflicts of Interest: The authors declare no conflict of interest.

\section{References}

1. Rezaee, Z. Business sustainability research: A theoretical and integrated perspective. J. Account. Lit. 2016, 36, 48-64. [CrossRef]

2. Rezaee, Z. Corporate sustainability: Theoretical and integrated strategic imperative and pragmatic approach. J. Bus. Inq. 2017, 16, 60-87.

3. Gilbert, D.U. Andreas Rasche and Sandra Waddock. Bus. Ethics Q. 2011, 21, 23-44. [CrossRef]

4. Aguilera, R.V.; Rupp, D.E.; Williams, C.A.; Ganapathi, J. Putting the S back in corporate social responsibility: A multilevel theory of social change in organizations. Acad. Manag. Rev. 2007, 32, 836-863. [CrossRef]

5. Starik, M.; Kanashiro, P. Toward a theory of sustainability management: Uncovering and integrating the nearly obvious. Organ. Environ. 2013, 26, 7-30. [CrossRef]

6. Wijen, F. Means versus ends in opaque institutional fields: Trading off compliance and achievement in sustainability standards adoption. Acad. Manag. Rev. 2014, 39, 302-323. [CrossRef]

7. United Nations Global Compact (UN Global Compact). Global Corporate Sustainability Report 2013. 2013. Available online: https://www.unglobalcompact.org/docs/about_the_gc/Global_Corporate_ Sustainability_Report2013.pdf (accessed on 9 August 2017).

8. Cruz, N.; Marques, R. Scorecards for sustainable local governments. Cities 2014, 39, 165-170. [CrossRef]

9. Corbett, C.J.; Klassen, R.D. Extending the Horizons: Environmental Excellence as Key to Improving Operations. Manuf. Serv. Oper. Manag. 2006, 8, 5-22. [CrossRef]

10. Pagell, M.; Wu, Z.; Murthy, N.N. The Supply Chain Implications of Recycling. Bus. Horiz. 2006, 50, $133-143$. [CrossRef]

11. Simoes, P.; Marques, R. On the economic performance of the waste sector. A literature review. J. Environ. Manag. 2012, 106, 40-47. [CrossRef] [PubMed]

12. Luchs, M.G.; Naylor, R.W.; Irwin, J.R.; Raghunathan, R. The Sustainability Liability: Potential Negative Effects of Ethicality on Product Preference. J. Mark. 2010, 74, 18-31. [CrossRef]

13. Carter, C.R.; Easton, P.L. Sustainable Supply Chain Management: Evolution and Future Directions. Int. J. Phys. Distrib. Logist. Manag. 2011, 41, 46-62. [CrossRef]

14. Fawcett, S.E.; Waller, M.A. Cinderella in the C-Suite: Conducting Influential Research to Advance the Logistics and Supply Chain Disciplines. J. Bus. Logist. 2011, 32, 115-121. [CrossRef]

15. Bansal, P.; McKnight, B. Looking Forward, Pushing Back and Peering Sideways: Analyzing the Sustainability of Industrial Symbiosis. J. Supply Chain Manag. 2009, 45, 26-37. [CrossRef]

16. Tate, W.L.; Ellram, L.M.; Kirchoff, J.F. Corporate Social Responsibility Reports: A Thematic Analysis Related to Supply Chain Management. J. Supply Chain Manag. 2010, 46, 18-44. [CrossRef]

17. Foerstl, K.; Azardegan, A.; Leppelt, T.; Hartmann, E. Drivers of Supplier Sustainability: Moving Beyond Compliance to Commitment. J. Supply Chain Manag. 2015, 51, 67-92. [CrossRef]

18. Zhu, Q.; Sarkis, J. Relationships between Operational Practices and Performance among Early Adopters of Green Supply Chain Management Practices in Chinese Manufacturing Enterprises. J. Oper. Manag. 2004, 22, 265-289. [CrossRef]

19. Rao, P.; Holt, D. Do Green Supply Chains Lead to Economic Performance? Int. J. Oper. Prod. Manag. 2005, 25, 898-916. [CrossRef]

20. Seuring, S.; Müller, M. From a literature review to a conceptual framework for sustainable supply chain management. J. Clean. Prod. 2008, 16, 1699-1710. [CrossRef]

21. Connelly, B.L.; Certo, S.T.; Ireland, R.D.; Reutzel, C.R. Signaling Theory: A Review and Assessment. J. Manag. 2011, 37, 39-67. [CrossRef]

22. Pagell, M.; Shevchenko, A. Why Research in Sustainable Supply Chain Management Should Have no Future. J. Supply Chain Manag. 2014, 50, 44-55. [CrossRef]

23. Fama, E.F. Agency problems and the theory of the firm. J. Political Econ. 1980, 88, 288-307. [CrossRef]

24. Fama, E.F.; Jensen, M.C. Separation of Ownership and Control. J. Law Econ. 1983, 26, 301-325. [CrossRef] 
25. Jensen, M.C.; Meckling, W.H. Theory of the firm: Managerial behavior, agency costs and ownership structure. J. Financ. Econ. 1976, 3, 305-360. [CrossRef]

26. Patten, D.M. Intra-industry disclosure in response to the Alaskan oil spill: A note on legitimacy theory. Account. Organ. Soc. 1992, 17, 471-475. [CrossRef]

27. Deegan, C. The legitimizing effect of social and environmental disclosures-A theoretical foundation. Account. Audit. Account. J. 2002, 15, 282-311. [CrossRef]

28. Spence, A.M. Market Signaling: Informational Transfer in Hiring and Related Screening Processes; Harvard University Press: Cambridge, UK, 1974.

29. Grinblatt, M.; Hwang, C. Signaling and the Pricing of New Issues. J. Financ. 1989, 44, 393-420. [CrossRef]

30. Freeman, R.E. Strategic Management: A Stakeholder Perspective; Prentice-Hall: Upper Saddle River, NJ, USA, 1984.

31. Freeman, R.E. Stakeholder Theory: The State of the Art; Cambridge University Press: Cambridge, UK, 2010.

32. Jensen, M. Value maximization, stakeholder theory, and the corporate objective function. Eur. Financ. Manag. 2001, 7, 297-317. [CrossRef]

33. Mitchell, R.K.; Agle, B.R.; Wood, D.J. Toward a Theory of Stakeholder Identification and Salience: Defining the Principle of Who and What Really Counts. Acad. Manag. Rev. 1997, 22, 853-886.

34. Davis, J.H.; Schoorman, F.D.; Donaldson, L. Toward a stewardship theory of management. Acad. Manag. Rev. $1997,22,20-47$.

35. Hernandez, M. Toward an understanding of the psychology of stewardship. Acad. Manag. Rev. 2012, 37, 172-193. [CrossRef]

36. Christmann, P.; Taylor, G. Firm self-regulation through international certifiable standards: Determinants of symbolic versus substantive implementation. J. Int. Bus. Stud. 2006, 37, 863-878. [CrossRef]

37. Delmas, M.A.; Montes-Sancho, M.J. Voluntary agreements to improve environmental quality: Symbolic and substantive cooperation. Strateg. Manag. J. 2010, 31, 575-601. [CrossRef]

38. Aravind, D.; Christmann, P. Decoupling of standard implementation from certification: Does quality of ISO 14001 implementation affect facilities' environmental performance? Bus. Ethics Q. 2011, 21, 73-102. [CrossRef]

39. King, A.; Prado, A.; Rivera, J. Industry self-regulation and environmental protection. In The Oxford Handbook of Business and the Natural Environment; Oxford University Press: Oxford, UK, 2012; pp. 103-131.

40. Bartley, T. Institutional Emergence in an Era of Globalization: The Rise of Transnational Private Regulation of Labor and Environmental Conditions. Am. J. Sociol. 2007, 113, 297-351. [CrossRef]

41. Chatterji, A.K.; Toffel, M.W. How firms respond to being rated. Strateg. Manag. J. 2010, 31, 917-945. [CrossRef]

42. Hopwood, A.G. Accounting and the environment. Account. Organ. Soc. 2009, 34, 433-439. [CrossRef]

43. Gray, R. Is accounting for sustainability actually accounting for sustainability ... And how would we know? An exploration of narratives of organizations and the planet. Account. Organ. Soc. 2010, 35, 47-62. [CrossRef]

44. Contrafatto, M. The institutionalization of social and environmental reporting: An Italian narrative. Account. Organ. Soc. 2014, 39, 414-432. [CrossRef]

45. Bebbington, J.; Larrinaga, C. Accounting and sustainable development: An exploration. Account. Organ. Soc. 2014, 39, 395-413. [CrossRef]

46. Unerman, J.; Chapman, C. Academic contributions to enhancing accounting for sustainable development. Account. Organ. Soc. 2014, 39, 385-394. [CrossRef]

47. Golicic, S.L.; Smith, C.D. A Meta-Analysis of Environmentally Sustainable Supply Chain Management Practices and Firm Performance. J. Supply Chain Manag. 2013, 49, 78-95. [CrossRef]

48. Friedman, M. The Social Responsibility of Business is to Increase its Profits. The New York Times Magazine. September 1970. Volume 33. Available online: https:/ / www.colorado.edu/studentgroups/libertarians / issues / friedman-soc-resp-business.html (accessed on 9 August 2017).

49. Dhaliwal, D.; Li, O.; Tsang, A.; Yang, Y. Voluntary non-financial disclosure and cost of equity capital: The initiation of corporate social responsibility reporting. Account. Rev. 2011, 86, 59-100. [CrossRef]

50. El Ghoul, S.E.; Geudhami, O.; Kwok, C.Y.; Mishra, D.R. Does corporate social responsibility affect the cost of capital? J. Bank. Financ. 2011, 35, 2388-2406. [CrossRef]

51. Bertoneche, M.; Lugt, C.V. Director Notes, the Sustainability Business Case: A Model for Incorporating Financial Value Drivers. June 2013. Available online: www.conferenceboard.org (accessed on 13 June 2015). 
52. Kiron, D.; Kruschwitz, N.; Haanaes, K.; Reeves, M.; Goh, E. The Innovation Bottom Line: The Benefit of Sustainability-Driven Innovation; Research Paper; MIT Sloan Management Review and the Boston Consulting Group: Cambridge, MA, USA, 2013; Volume 54, pp. 69-73. Available online: http:/ / sloanreview.mit.edu/ sustainability (accessed on 21 August 2017).

53. Ng, A.C.; Rezaee, Z. Business sustainability performance and cost of equity capital. J. Corp. Financ. 2015, 34, 128-149. [CrossRef]

54. Jain, P.K.; Jain, A.; Rezaee, Z. Value-relevance of corporate social performance: Evidence from Short Selling. J. Manag. Account. Res. 2016, 28, 29-52. [CrossRef]

55. Huang, X.B.; Watson, L. Corporate social responsibility research in accounting. J. Account. Lit. 2015, 34, 1-16. [CrossRef]

56. Lys, T.; Naughton, J.; Wang, C. Signaling through corporate accountability reporting. J. Account. Econ. 2015, 60, 56-72. [CrossRef]

57. Guthrie, J.; Parker, L.D. Corporate social reporting: A rebuttal of legitimacy theory. Account. Bus. Res. 1989, 19, 343-352. [CrossRef]

58. Tilling, M.V. Some thoughts on legitimacy theory in social and environmental accounting. Soc. Environ. Account. J. 2004, 24, 3-7. [CrossRef]

59. Rezaee, Z. Business Sustainability: Performance, Compliance, Accountability and Integrated Reporting; Greenleaf Publishing Limited: Oxford, UK, 2015.

60. Meyer, J.W.; Rowan, B. Institutionalized organizations: Formal structure as myth and ceremony. Am. J. Sociol. 1977, 83, 340-363. [CrossRef]

61. Edelman, L.B. Legal ambiguity and symbolic structures: Organizational mediation of civil rights. Am. J. Sociol. 1992, 95, 1401-1440. [CrossRef]

62. Tolbert, P.S.; Zucker, L.G. Institutional Sources of Change in the Formal Structure of Organizations: The Diffusion of Civil Service Reform, 1880-1935. Adm. Sci. Q. 1983, 28, 22-39. [CrossRef]

63. Roberts, J. The Modern Firm; Oxford University Press: Oxford, UK, 2004.

64. Sarkis, J.; Zhu, Q.; Lai, K. An organizational theoretic review of green supply chain management literature. Int. J. Prod. Econ. 2011, 130, 1-15. [CrossRef]

65. Touboulic, A.; Walker, H. Theories in sustainable supply chain management: A structured literature review. Int. J. Phys. Distrib. Logist. Manag. 2015, 45, 16-42. [CrossRef]

66. Kiron, D.; Kruschwitz, N.; Haanaes, K.; Reeves, M.; Fuisz-Kehrbach, S.; Kell, G. Joining Forces: Collaboration and Leadership for Sustainability. In MIT Sloan Management Review; The Boston Consulting Group, and the United Nations Global Compact (UNGC). 12 January 2015. Available online: http:/ / marketing.mitsmr. com/PDF/56380-MITSMR-BGC-UNGC-Sustainability2015.pdf?cid=1 (accessed on 25 February 2016).

67. Hahn, T.; Figge, F.; Pinkse, J.; Preuss, L. Trade-offs in corporate sustainability: You can't have your cake and eat it. Bus. Strateg. Environ. 2010, 19, 217-229. [CrossRef]

68. Global Reporting Initiative (GRI). G4 Sustainability Reporting Guidelines. 2013. Available online: https: / / www.globalreporting.org/resourcelibrary/GRIG4-Part1-Reporting-Principles-and-StandardDisclosures.pdf (accessed on 4 March 2017).

69. Porter, M.E.; Kramer, M.R. Creating Shared Value. Harvard Business Review, January-February 2011. pp. 62-77. Available online: https://hbr.org/2011/01/the-big-idea-creating-shared-value (accessed on 9 August 2017).

70. McGrath, R.G.; Ferrier, W.J.; Mendelow, A.L. Real options as engines of choice and heterogeneity. Acad. Manag. Rev. 2004, 29, 86-101. [CrossRef]

71. Committee for Economic Development (CED). Built to Last: Focusing Corporations on Long-Term Performance. 2007. Available online: www.ced.org/docs/report/report_corpgov2007.pdf (accessed on 22 September 2016).

72. KPMG. Beyond Quarterly Earnings: Is the Company on Track for Long-Term Success? Spring 2013 Audit Committee Roundtable Report. 2013. Available online: https:/ /boardleadership.kpmg.us/content/dam/blc/ pdfs / 2013/aci-spr-2013-roundtable-report-beyond-quarterly-earnings.pdf (accessed on 2 October 2016).

73. Schaltegger, S.; Wagner, M. Integrative management of sustainability performance, measurement and reporting. Int. J. Account. Audit. Perform. Eval. 2006, 3, 1-19. [CrossRef]

74. Burritt, R.; Schaltegger, S. Sustainability accounting and reporting: Fad or trend? Account. Audit. Account. J. 2010, 23, 829-846. [CrossRef] 
75. The International Integrated Reporting Council (IIRC). Capitals Background Paper for <IR>. March 2013, p. 6. Available online: http:/ /integratedreporting.org/wp-content/uploads/2013/03/IR-Background-PaperCapitals.pdf (accessed on 7 April 2015).

76. Sustainability Accounting Standards Board (SASB). Conceptual Framework of Sustainability Accounting Standard Board. October 2013. Available online: http://www.sasb.org/wp-content/uploads/2013/10/ SASB-Conceptual-Framework-Final-Formatted-10-22-13.pdf (accessed on 10 August 2017).

77. Simnett, R.; Vanstraelen, A.; Chua, W.F. Assurance on general purpose non-financial reports: An international comparison. Account. Rev. 2009, 84, 937-967. [CrossRef]

78. CFA Institute. Environmental, Social and Governance (ESG) Survey. June 2015. Available online: http: / /irrcinstitute.org/pdf/FINAL-CFA-ESG-Study-August-2015.pdf (accessed on 16 June 2015).

(C) 2018 by the author. Licensee MDPI, Basel, Switzerland. This article is an open access article distributed under the terms and conditions of the Creative Commons Attribution (CC BY) license (http:/ / creativecommons.org/licenses/by/4.0/). 